\title{
Important qualities of a perfect human in youth education
}

\author{
Dilbar Artiqovna Artiqova ${ }^{1}$, Abdunosirova Halima Ertdllayevna ${ }^{2}$ \\ ${ }^{1,2}$ Tashkent Institute of Textile and Light Industry \\ 'dotcent of the department "Social Sciences" \\ ${ }^{2}$ Senior lecturer of the department "Social Sciences"
}

\begin{abstract}
The article examines the important qualities of an ideal person, such as generosity, nobility, kindness, generosity. The science of futuwvat is analyzed, and on the basis of the sources the generality of generosity is substantiated, which is its practical expression. The importance of these qualities in the upbringing of modern youth is emphasized.

Keywords: Futuvwat, generosity, nobility, benevolence, generosity, courage, cabbage, courage, ahiya or fatiyah, generosity, humanity, high moral standards, goodness - these are mercy, Sufis, courage, national and universal value, sincerity, love.
\end{abstract}

\section{Introduction}

The formation of a generous and harmonious human personality has always been an integral part of the noble dream of our people, our rich spirituality, and this is deeply reflected in the wisdom of our sages. In their philosophical and scientific views, our great ancestors argued that it is impossible to achieve high perfection without internal motivation, spiritual aspiration, strength and zeal, that is, motive and impulse that lead to the improvement of a person, the formation of high human qualities in his behavior. In this regard, one of the urgent problems is highlighting the importance of the futuvwat of the «Courage Program» of science and its practical manifestation of generosity in the education of young people [1, p. 137-149]. After all, "dedicating your life to serving friends is not getting tired of thinking only good things," having good manners, sharing your wealth with others, helping those in need, defending the honor of teachers, friends, and brothers. to win the conversation ..." $[2, \mathrm{p} .3]$. One of the noble qualities of a harmoniously developed person is the main idea of «5 important initiatives in the education of youth ...» [3], put forward by the President of the Republic of Uzbekistan Shavkat Mirziyoyev.

\section{MAIN BODY.}

Throughout history, there have been the aforementioned true human qualities that have come together in a team and realized their noble intentions. They were called brave, generous, ahi or fatis. In the ancient cities of Khorasan and Movarounnahr, the movement of valor or futuvatism has been widespread since the 10th century. Futuvatists followed certain rules, aspired to spiritual and physical maturity, always set an example of courage and nobility, actively fought against oppression and injustice. For futuvatists, not the wealth of the world, but human dignity was not ignored by gold and silver, but they saw in it a tool of spiritual development. Hasan Basri, Tomaris, Shirak, which are free symbols of generosity and courage in our people. The courage, generosity and courage of people like Spitamin, Temur Malik, Mukanna, Mahmud Tarobi, for the freedom of their people, homeland and loved ones would be a great light if they became a model for our youth today. In ancient Bukhara, the wealthy who today owned large fortunes displayed universal generosity, exemplified by some of the wealthy businessmen who built high-rise buildings and owned a series of cars. They voluntarily brought a certain part of their wealth to the room of the Mir Arab madrasah, which was always open without giving their names. The helpless, the poor and the needy simply conscientiously took what they needed. Such generosity, honesty, humanity, nobility is worth describing and promoting today.

Charity - to do all this not only for yourself, but also for others; futuwwat - to do good to others, but not to mention it. Alisher Navoi in his book Mahbub-ul-Kulub specifically interprets these two words as a term of moral and social meaning: According to Navoi's figurative description, «cabbage and mercy are parents, loyalty and modesty are two children.» Creativity, philosophy and lifestyle of Alisher Navoi is a truly vivid example of humanity, generosity and tolerance. In addition to promoting the idea of raising an ideal person throughout his life, our ancestor not only wrote in his works about the high human qualities of generosity, kindness, helping widows, alleviating the plight of people, but also was a leader among people. Alisher Navoi said: «People should also look at existence from the point of view of human interests, create humanity and fight for its destruction when there are events that contradict it.» From this point of view, a person has a high level of human interests and dignity, be it the process of upbringing, a role in society, a role in the family, a child, a role or duty to his wife, a fair approach to justice in any situation. is designed to eliminate potential problems. According to Alisher Navoi, man is the crown of all creation. He must live with honor, purity and beauty "[5]. In his works, Alisher Navoi raises the spiritual power, wealth, beauty and humanity of a person to the highest peaks. He sings about sincere love, devotion, generosity to humanity.

According to historical records, our great ancestor set himself the goal of building 1001 buildings that will benefit society and people at his own expense. As a result, in 1480-500, he built several madrasahs, 40 
robots (passenger stops), 17 mosques, 10 khanakas, 9 baths, 9 bridges and 20 swimming pools at his own expense. In madrassas and medical institutions such as Ikhlosia and Halosia, students taught science for free and cured many patients. At his own expense, he organized the delivery of water from distant mountains to the city of Mashhad. Before the winter and summer seasons, she distributed clothes and food to the needy and needy [4, p.39]. Sources say that Alisher Navoi did not use his life salary for his own needs, but distributed it to those in need.

Generosity is a manifestation of goodness and at the same time a means of feeling happy. Because when a person does good to others, he himself receives spiritual food from everything he does. He will enjoy his donations, gifts and generosity more than anyone who has done him good. He is pleased with the charity he gives and understands that «the one who gives with pleasure is more generous than the one who hurts.» The hadith says: "Every good deed is charity. What a person spends on himself and his family is recorded as charity for himself. All that he spends to maintain his honor is also a charity for himself, and Allah is obliged to repay what he spends».

The famous "Qaboosnoma", created in the 11th century, has a special chapter on heroism (Chapter 44), which states that "courage is essentially three things: one is great, the other is great, if you do what you say, the third is great if you do not contradict the truth, the third is great if you promote good deeds, all other qualities in a person are under these three» [7, p.152]. Then the rest of the adjectives are listed. An important aspect of the Nightmare is that In addition to the general requirements of Futuwwat, it takes into account all social conditions, kindness, generosity, mercy and responsibility of these requirements. There are dozens of interpretations of Futuwwat in the sources. This is especially true for Sufis who were formerly brave, or who adopted courage, or who accepted courage Fariduddin Attar's Futuvvatnama describes the demands of Futuvvat.

Islam encourages people to be generous and kind. Indeed, the Messenger of Allah (peace and blessings of Allaah be upon him) was faster than a strong wind in showing kindness to people» (Reported by al-Bukhari and Muslim). He was given the treasures of the earth, the keys to his country, and mining was allowed. He was also conquered by Hijaz, Yemen, Damascus, parts of Iraq, the Arabian Peninsula and brought a lot of booty, tribute and alms, and the kings of the surrounding area sent him countless gifts. But he did not consider them private property. They did not use any of them for their own use. He said: «If I have gold like Mount Uhud, I will not be happy to take a dinar from it, except for that which is intended to be used in the path of Allah» [9]. They said. When a generous person always gives, his heart is filled with joy, his heart is filled with peace, and his face is filled with satisfaction. The idea of an ideal person is a noble feeling of national and universal character, embodying the highest spiritual and physical perfection of mankind, always encouraging him to do good. This idea has led not only people, but entire nations to great progress, inspiring them to unprecedented achievements in the garden of spirituality and enlightenment. There is no future for a nation that does not dream of perfection and does not care about bringing up a harmoniously developed generation. We can proudly say: «Our people are a mighty force, living by its thousand-year traditions and experience, indelible memory and great feelings». Indeed, the concept of generosity is not limited to misappropriation of property, but its meaning is much broader, and its appearance is much broader. As al-Ghazali said: "Any good deed is charity, and the one who conducts a good deed is like the one who does the same good deed" [6, p.126].

As noted in the Address of the President of the Republic of Uzbekistan Shavkat Mirziyoyev to the Oliy Majlis: "Let us never forget one truth: we are a people with a great history, a great state and a great culture. We are great people who never run away from work, are not afraid of adversity, appreciate justice, are decisive and courageous "[8]. Naturally, in the current period there are great discoveries and achievements in the field of science and technology, which have a significant impact on the content and forms of the task of spiritual and cultural education of schoolchildren. This factor should always be kept in mind.

\section{Conclusion.}

In the spiritual and cultural education of students, along with national values, it is necessary to effectively use universal human values, as well as instill in them modern achievements of universal development. All this must be taken into account when planning the spiritual and cultural education of student youth.

\section{REFERENCES:}

1. Yurtoglu G. About the cult of Otman Baba [About the tradition of Otman Baba]. Turkish Culture and Haci Bektas Veli - Research Magazine. Volume 80, 2016.

2. Hussein Voiz Kashifi «Futuvatnomai Sultani» T., 1994.

3. President: 5 important initiatives in youth education. http://www.uzdaily.uz/uz/post/5328.

4. Oybek. «Navoi». «East». 1995.

5. 5.https://uz.m.wikipedia.org/wiki/Alisher_Navoiy.

6. Abu Hamid al-Ghazali. Ihyo Ulumiddin (Book of the Knowledge of the World). Shark Publishing and Printing Society. T., 2015. 
7. Caicovus. «Qaboosnoma». Tashkent, Meros Publishing House, 1992.

8. Message from the President of the Republic of Uzbekistan Shavkat Mirziyoyev to the Oliy Majlis. Newspaper «Trust», January 25, 2020 No. 15-16 (4301).

9. Generosity and conscientiousness - Islam.uz.islom.uz. Article 5 August 2017. 